\title{
Identifikasi Bakteri Rumput Laut Kappaphycus alvarezii Berdasarkan Musim Tanam di Perairan Maluku Tenggara
}

\author{
Identification Bacteria Kappaphycus alvarezii Based on Planting Season at South Eeast \\ Mollucas
}

\author{
Nally. Y.G.F. Erbabley ${ }^{(1)}$, Dominggas M. Kelabora ${ }^{(2)}$ \\ ${ }^{(1)}$ Program Studi Teknologi Budidaya Perikanan Politeknik Perikanan Negeri Tual \\ ${ }^{(2)}$ Program Studi Teknologi Budidaya Perikanan Politeknik Perikanan Negeri Tual \\ Jln. Raya langgur-Sathean, Km 6. Kab Maluku Tenggara 97611 \\ Tlp/Fax (0916) 21377 ; PO Box 1001 \\ E-mail korespondensi : nallyerbabley@gmail.com
}

\begin{abstract}
Abstrak
Penyakit ice-ice merupakan masalah utama dalam budidaya rumput laut Kappaphycus alvarezii yang menimbulkan kerusakan pada permukaan thallus. Penyebarannya sangat cepat dan dapat menimbulkan kematian, sehingga mengakibatkan kerugiaan yang cukup besar dalam budidaya. Kejadian penyakit ice-ice bersifat musiman, menular dan disebabkan oleh infeksi sekunder bakteri. Tujuan penelitian ini adalah melakukan identifikasian bakteri penyebab penyakit ice-ice berdasarkan musim tanam. Penelitian dilakukan di laboratorium hama dan penyakit Balai Budidaya Laut Ambon. Isolasi bakteri diambil dari thallus yang terserang penyakit ice-ice dan dari sampel air lokasi budidaya selanjutnya identifikasi dengan menggunakan metode uji biokimia. Hasil penelitian menunjukan bakteri yang menginfeksi rumput laut di perairan Maluku Tenggara pada lokasi Sathean yaitu bakteri Pseudomonas stutzeri, Aeromonas faecalis, Vibrio alginolitycus, Pseudomonas fluorescens sedangkan bakteri yang terdapat di perairan adalah bakteri Vibrio alginolitycus, Pseudomonas fluorescens. Pada musim tanam ke III-IV periode April-Juli. Untuk lokasi Letvuan jenis bakteri yang ditemukan adalah bakteri Pseudomonas stutzeri, Aeromonas faecalis,. pada musim tanam VII-VIII periode Oktober-November. Berdasarkan hasil yang diperoleh maka disimpulkan bahwa Bakteri dominan yang menginfeksi rumput laut di perairan Maluku Tenggara adalah dari genus Pseudomonas dan Vibrio serta terjadi pada musim pancarobah atau musim peralihan dari musim hujan ke musim kemarau periode April-Juli.
\end{abstract}

Kata Kunci : Identifikasi Bakteri, Penyakit ice-ice, Musim Tanam

\begin{abstract}
Abstrack
Ice-Ice disease is a main problem in the cultivation of seaweed Kappaphycus alvarezii which causing damage on the surface of the thallus. The spread is very rapid and cause death so can cause big loss in cultivation. Insidence of Ice-Ice disease are seasonal, contagious and caused by secondary bacterial infection. The purpose of this study is to identify the bacteria that cause ice-ice disease based on the growing season. The research was conducted in pest and disease laboratory of Ambon Sea Aquaculture Center. Bacterial isolation was taken from the ice-ice disease thallus and from the water sample of the cultivation location further identification using the biochemical test method. The results showed bacteria that infect seaweed in the waters of Southeast Maluku at the location of Sathean are bacteria Pseudomonas stutzeri, Aeromonas faecalis, Vibrio alginolitycus, Pseudomonas fluorescens while bacteria in the waters are bacteria Vibrio alginolitycus, Pseudomonas fluorescens. For the location Letvuan type of bacteria found is bacteria Pseudomonas stutzeri, Aeromonas faecalis,. In the planting season to III-IV period April-July, many bacteria are found to infect seaweed in the waters of Southeast Mollucas. Based on the results obtained it is concluded that the dominant bacteria that infect seaweed in the waters of Southeast Maluku is from the genus Pseudomonas and Vibrio occur in transition season from the rainy season to the dry season April-July period.
\end{abstract}

Keywords: Bacterial Identification, Ice-ice Disease, Planting Season 


\section{Pendahuluan}

Rumput laut (seaweeds) merupakan salah satu komoditas budidaya laut yang mempunyai prospek cerah karena memiliki nilai penting bagi masyarakat. Aspek penting dan karakteristik menguntungkan yang berkaitan dengan pengembangan budidaya rumput laut ini antara lain meliputi aspek ekonomi, terutama dimanfaatkan sebagai bahan pangan seperti lalapan, sayur, acar, manisan, kue dan obat (Anggadireja dkk, 2011). Keberhasilan budidaya rumput laut sangat dipengaruhi oleh faktor-faktor seperti kesesuaian lahan, penguasaan teknologi budidaya, dan musim tanam. Masalah yang sering dihadapi oleh pembudidaya rumput laut adalah pertumbuhan yang kurang optimal dan hasil panen yang menurun serta penyediaan benih yang tidak kontinyu pada bulan-bulan tertentu karena perubahan kondisi lingkungan yang ekstrim (Supatno dkk, 2010). Permasalahan lain yang sering timbul pada usaha budidaya rumput laut yaitu adanya serangan penyakit ice-ice. Dengan gejala umumnya ditandai dengan pemutihan pada bagian pangkal thallus, tengah dan ujung thallus muda, yang diawali dengan perubahan warna thallus menjadi putih bening atau transparan (DKP, 2004).

Penyakit yang sering dijumpai pada budidaya rumput laut adalah penyakit bakterial, yaitu penyakit "ice-ice"/white spot. Penyakit "ice-ice" merupakan kendala utama budidaya rumput laut Kappaphycus yang terutama disebabkan oleh perubahan lingkungan seperti arus yang lemah, suhu yang sangat tinggi, defisiensi nutrient dan kecerahan perairan. Kecerahan air yang sangat tinggi akibat rendahnya kelarutan unsur hara Nitrat dan Phosfat dalam perairan juga merupakan penyebab munculnya penyakit tersebut. Hal ini sejalan dengan pendapat Largo., et al (1995) bahwa penyebab penyakit ice-ice karena perubahan lingkungan yang tidak sesuai untuk pertumbuhan sehingga mengakibatkan menurunnya daya tahan rumput laut. Selanjutnya Musa dan Wei (2008) mengatakan bahwa terjadinya penyakit ini disebabkan oleh bakteri patogen tertentu. Keberadaan bakteri-bakteri tersebut bukan menjadi penyebab utama terjadinya penyakit ice-ice pada tallus, tetapi hanya merupakan penyebab kedua (secondary impact). Kemungkinan efektifitas serangan bakteri hanya terjadi pada saat pertumbuhan tanaman terhambat serta stress yang diakibatkan perubahan kondisi lingkungan yang mendadak seperti perubahan salinitas, suhu dan intensitas cahaya.

Kabupaten Maluku Tenggara terletak pada posisi $5^{\circ}-6,5^{\circ}$ Lintang Selatan dan $131^{\circ}$ - 133,5 $5^{\circ}$ Bujur Timur, terdiri atas 1 gugusan Kepulauan yaitu Gugusan Kepulauan Kei yang terdiri atas Kepulauan Kei Kecil dengan Luas seluruhnya $722,62 \mathrm{Km}^{2}$ dan Pulau Kei Besar dengan Luas 550,05 $\mathrm{Km}^{2}$. Iklim perairan Maluku Tenggara dipengaruhi oleh Laut Banda, Laut Arafura dan Samudera Indonesia juga dibayangi oleh Pulau Irian di Bagian Timur dan Benua Australia di Bagian Selatan, sehingga sewaktu-waktu terjadi perubahan. Musim Timur berlangsung dari bulan April sampai Oktober dimana musim ini adalah musim Kemarau. Musim Barat berlangsung dari bulan Oktober sampai Februari. Musim hujan pada bulan Desember sampai Februari dan yang paling deras terjadi pada bulan Desember dan Februari yang berakibat terhadap perubahan kondisi perairan Maluku Tenggara. Tujuan penelitian ini adalah mengidentifikasi jenis bakteri pada $K$. Alvarezii yang terserang penyakit ice-ice berdasarkan musim tanam pada lokasi yang berbeda.

\section{Bahan Dan Metode}

\section{Waktu dan Lokasi Pengambilan Sampel}

Sampel K.alvarezii diambil dari lokasi budidaya rumput laut di perairan Sathean dan Letvuan Kabupaten Maluku Tenggara, masing-masing sebanyak 100 gr. Sampel air diambil bersamaan dengan pengambilan sampel rumput laut.

\section{Metode Penanganan Sampel}

Sampel K.alvarezii diambil dari bagian ujung thallus dan pangkal rumput laut yang, terserang penyakit ice-ice yang diambil dari lokasi budidaya, dari varietas colkat yang diberi kode (RLC) dan varietas hijan yang diberi kode (RLH) dari perairan Sathean dan perairan Letvuan. Sampel disimpan dalam cool box yang telah diberi es balok untuk dibawa ke Laboratorium Balai Budidaya Laut 
Ambon. Selanjutnya sampel rumput laut yang terinfeksi bakteri akan dilakukan isolasi dan identifikasi bakteri. Pengukuran parameter kualitas air dilakukan secara insitu pada lokasi budidaya, dengan menggunakan alat Automatic Watersample dan Digital Instruments. Parameter yang diuji adalah $\mathrm{pH}$ air, DO (Dissolved Oxygen), suhu, salinitas.

\section{Isolasi dan Identifikasi Bakteri}

Isolasi awal dilakukan pada media TCBS (thiosulphate citrate bile salt sucrosa agar) dan media TSA (thiosulphate sucrosa agar) masing-masing sebanyak 10 plate yang mana masing-masing plate diisolasi dari bagian ujung dan pangkal rumput laut yang mengalami pemutihan, dengan tujuan untuk mengidentifikasi mikroorganisme penyebab penyakit, kemudian plate-plate tersebut diinkubasi pada suhu $28{ }^{0} \mathrm{C}$ selama 24 jam untuk pengamatan pertumbuhan bakteri pada media. Selanjutnya dilakukan isolasi murni dengan cara, mengambil koloni bakteri dengan menggunakan jarum ose dari sampel isolasi awal, dengan berpatokan pada nomor isolat dan di isolasi pada media tanam TCBS, GSP, Kanamicyn dan diisolasi pada suhu 35 ${ }^{0} \mathrm{C}$ selama 24 jam. Setelah 24 jam selanjutnya dilakukan isolasi ke media biokimia yang meliputi : Test Oksidase, Test Katalase, Test OF (Oksidasi-Fermentasi), Test Citrat, Test TSI (Triple Segar Iron Agar), Uji Indol, Test Produksi Asam dari Beberapa Karbohidrat
(Sukrosa, L-Arabinosa, D-Glukosa, DMannitol dan Myo-Inositol). untuk mengidentifikasi jenis bakteri yang menyerang rumput laut dan sampel air dengan menggunakan petunjuk identifikasi menurut Cowan. S.T (1981) serta Krieg, N.R dan John. G. Hold (1984).

\section{Hasil Dan Pembahasan}

Isolasi untuk identifikasi bakteri diambil dari rumput laut varietas coklat (RLC) dan varietas hijau (RLH) dari lokasi Sathean dan Letvuan perairan Maluku Tenggara, disertai dengan sampel air dari lokasi penelitian. Tanda-tanda rumput laut yang terserang penyakit bakteri pada kedua lokasi cenderung sama yaitu perubahan pada thallus (berwarna putih), produksi lendir berlebihan, patah dan terkelupas pada bagian thallus, pertumbuhan lambat dan bentuk thallus tidak normal.

Uji presumtif dilakukan pada kedua varietas dengan tujuan untuk memudahkan dalam tahap identifikasi, dengan mengetahui genus dari bakteri yang ditumbuhkan. Pengujian yang dilakukan meliputi uji gram untuk mengetahui apakah bakteri bersifat gram positif atau gram negative, uji katalase dan uji oksidase Hasil pengujian dapat dilihat pada Tabel 1 .

Hasil karakteristik dan identifikasi bakteri terhadap isolat bakteri yang diisolasi dari rumput laut yang terserang penyakit ice-ice dapat terlihat pada Tabel 2.

Tabel 1. Pengujian Presumtif

Table 1. Precision Testing

\begin{tabular}{clcc}
\hline No & Pengujian & \multicolumn{2}{c}{ Sampel } \\
\cline { 3 - 4 } & & RLS & RLL \\
\hline 1 & Gram & - & - \\
2 & Katalase & + & + \\
3 & Oksidase & + & + \\
\hline
\end{tabular}

Ket: RLS=Rumpul Laut Sathean, RLL=Rumput Laut Letvuan

Tabel 2. Identifikasi Bakteri Rumput Laut Yang Terserang Ice-Ice Table 2. Identification of Ice-Ice Seaweed Bacteria

\begin{tabular}{cccc}
\hline Lokasi & Sampel & Jenis bakteri & $\begin{array}{c}\text { Total Bakteri } \\
(\text { koloni } / \mathrm{mL})\end{array}$ \\
\hline Sathean & Rumput laut & $\begin{array}{c}\text { Pseudomonas stutzeri } \\
\text { Aeromonas faecalis }\end{array}$ & 26 \\
& & Aeromonas faecalis & 35 \\
& & Vibrio alginolitycus & 82
\end{tabular}


Nally. Y.G.F. Erbabley : Identifikasi Bakteri Rumput Laut Kappaphycus alvarezii Berdasarkan Musim Tanam di Perairan Maluku Tenggara

\begin{tabular}{cccc}
\hline Lokasi & Sampel & Jenis bakteri & $\begin{array}{c}\text { Total Bakteri } \\
\text { (koloni/mL) }\end{array}$ \\
\hline & \multirow{3}{*}{ Sampel air } & Pseudomonas fluorescens & 29 \\
& & $\begin{array}{c}\text { Vibrio alginolitycus } \\
\text { Pseudomonas fluorescens }\end{array}$ & 172 \\
\hline Letvuan & Rumput laut & Pseudomonas stutzeri & 112 \\
& & Aeromonas faecalis & 16 \\
& & Vibrio alginolitycus & $<5$ \\
& & Actinobassilus sp & 10 \\
& Sampel air & Pseudomonas fluorescens & 118 \\
\hline
\end{tabular}

Sumber: Diolah dari data primer

Tabel 2, memperlihatkan jenis bakteri yang dominan lokasi Sathean di dominasi oleh bakteri Vibrio algynolyticus, sebaliknya pada lokasi Letvuan didominasi oleh bakteri Pseudomonas fluorescens, hal ini terlihat dari total jumlah bakteri (koloni/mL) tiap-tiap bakteri yang diperoleh. Hail identifikasi pada sampel air laut menunjukan bakteri yang sama juga ditemukan pada sampel air laut, hal ini menunjukkan adanya indikasi bahwa bakteri yang diisolasi dari air laut dapat menginfeksi ujung thallus rumput laut yang telah putus dan luka sehingga tidak bisa lagi tumbuh thallus yang baru, bahkan semakin membuat tallus menjadi busuk. Sedangkan Jenis bakteri yang dominan diisolasi dari air laut dan rumput laut yang terserang penyakit ice-ice adalah Pseudomonas sp, dan Aeromonas faecalis.

Penelitian lain terhadap bakteri yang menyebabkan penyakit ini pernah dilakukan oleh Laboratorium mikrobiologi Pusat Penelitian Oseanografi (P2O) LIPI dan hasilnya diduga ada delapan jenis bakteri yang menimbulkan penyakit ice-ice, namun patogenitas bakteri tersebut belum diketahui. Kemudian dilanjutkan dengan penelitian uji patogenitas dari delapan bakteri tersebut yang hasilnya menunjukan hanya lima bakteri yang dapat menimbulkan penyakit ice-ice. Lima bakteri tersebut adalah : Pseudomonas fluorescens, P. nigricaciens, vibrio granii, Bacillus cereus, dan $V$. agarliquefaciens. Sedangkan $P$. gelatica, $P$. ichtyodermis dan $B$. megaterium tidak memiliki patogenitas, sehingga tidak menyebabkan gejala penyakit ice-ice. Bakteri yang memiliki daya patogenitas tertinggi adalah $V$. Agarliquefaciens (Nasution, 2005). Selanjutnya penelitian yang dilakukan oleh Saraswati (2016) juga menemukan bakteri yang menginfeksi rumput laut Eucheuma spinosum pada perairan pantai Kutuh Bali, didominasi oleh bakteri $V$. algynolyticus dan P.aeruginosa. Hasil penelitian lain yang dilakukan berdasarkan teknik isolasi dan sekuensing 16S-rRNA telah diidentifikasi beberapa jenis bakteri yang berkembang dalam perairan yang juga teridentifikasi dalam tallus rumput laut yang terserang penyakit ice-ice di perairan Sulawesi Selatan. Walaupun demikian disimpulkan bahwa keberadaan bakteri-bakteri tersebut bukan menjadi penyebab utama terjadinya penyakit ice-ice pada thallus, tetapi hanya merupakan penyebab kedua (secondary impact).

Hanna et al. (1992) dalam Saraswati (2016), mengatakan bahwa $V$. alginolyticus merupakan bakteri berbentuk basil (batang) dan bersifat motil (dapat bergerak), berhabitat alami di lingkungan akuatik dan umumnya berasosiasi dengan bakteri dari spesies vibrio secara langsung dan akan menimbulkan penyakit pathogen, yang dapat menyebabkan kematian biota laut dan secara tidak langsung bakteri yang terbawa biota laut seperti ikan dan rumput laut akan dikonsumsi oleh manusia, sehingga menyebabkan penyakit pada manusia. Lebih lanjut dikatakan Pseudomona sp termasuk bakteri gram negatif. Bakteri ini bersifat aerob, katalase positif, oksidase positif, tidak mampu memfermentasi tetapi dapat mengoksidasi glukosa/karbohidrat lain, tidak 
berspora, tidak mempunyai selubung (sheat) dan mempunyai flagel monotrika (flagel tunggal pada kutub) sehingga selalu bergerak. Pseudomonas sp merupakan patogen utama bagi manusia, bakteri ini kadang-kadang mengkoloni pada manusia dan menimbulkan infeksi apabila fungsi pertahanan inang abnormal. Bakteri $P$. fluorescens termasuk dalam golongan bakteri thermofilik yaitu bakteri yang berkembang di suhu tinggi, tumbuh dalam sumber air panas, tanah padang pasir, dan spa.

Selanjutnya dilakukan pengamatan bakteri berdasarkan musim tanam pada lokasi penelitian, hasilnya dapat dilihat pada Tabel 3.

Tabel 3. Jenis bakteri Yang Ditemukan Berdasarkan Musim Tanam

Table 3. Type of Bacteria Found Based on Planting Season

\begin{tabular}{llll}
\hline \multirow{2}{*}{ No } & Periode Tanam & \multicolumn{2}{c}{ Jenis Bakteri (Sel/koloni) } \\
\cline { 3 - 4 } & & \multicolumn{1}{c}{ Sathean } & \multicolumn{1}{c}{ Letvuan } \\
\hline 1. & I - II (Januari - Maret) & Aeromononas faecalis & Aeromonas faecalis \\
\hline 2. & III - IV (April - Juli) & $\begin{array}{l}\text { Pseudomonas stutzeri } \\
\text { Aeromonas faecalis } \\
\end{array}$ & Vibrio alginolitycus \\
& & Pseudomonas flurescens & \\
\hline 3. & V - VI (Agustus - September) & $\begin{array}{l}\text { Aeromonas faecalis } \\
\text { Vibrio alginolitycus }\end{array}$ & Actinobacillus sp \\
& & Pseudomonas flurescens & \\
\hline 4. & VII- VIII (Oktober - Desember) & $\begin{array}{l}\text { Aeromonas faecalis } \\
\text { Vibrio alginolitycus }\end{array}$ & Pseudomonas stutzeri \\
& & Aeromonas faecalis \\
& & Pseudomonas flurescens & \\
\hline
\end{tabular}

Hasil pengamatan infeksi bakteri pada rumput laut berdasarkan musim tanam, ditemukan bahwa pada musim tanam ke IIIIV periode April-Juli, bakteri banyak menginfeksi rumput laut pada lokasi Sathean, hal ini diduga akibat perubahan musim dari musim hujan ke musim kemarau yang berpengaruh kepada perubahan kandungan nutrien di perairan Sathean. Sedangkan untuk lokasi Letvuan terjadi pada musim tanam VII-VII periode Oktober-Desember. disebabkan karena pada periode ini intensitas hujan yang turun cukup tinggi sehingga memungkinkan terjadinya perubahan kandungan nutrien dalam perairan dan penurunan salinitas perairan. Air hujan yang masuk ke perairan mengandung kandungan NO3 (nitrat) sebesar $2 \%$ yang juga sangat berpengaruh terdapat proses pertumbuhan thallus rumput laut (Effendi, 2000).

Pola atau kalendar musim tanam rumput laut dapat dipengaruhi oleh kondisi lingkungan perairan dan kondisi iklim (klimatologi dan meteorologi). Kondisi iklim yang paling diperhatikan dalam penyusunan kalendar musim tanam rumput laut adalah musim panas dan penghujan. Intensitas curah hujan yang sangat tinggi akan memengaruhi kondisi salinitas perairan berupa turunnya nilai salinitas yang sesuai untuk budidaya rumput laut. Rumput laut jenis $K$. alvarezii merupakan rumput laut yang tidak tahan terhadap kisaran salinitas yang lebar. Salinitas yang sesuai untuk pertumbuhannya adalah 28-35 ppt, namun pertumbuhan optimal dicapai pada salinitas 32-35 ppt (Sudradjat, 2009; Parenrengi et al., 2011). Menurut Neksidin (2013), perubahan salinitas yang lebih rendah berpengaruh terhadap proses osmoregulasi pada rumput laut. Pada saat salinitas perairan rendah terjadi proses penyerapan air oleh rumput laut lebih banyak, akibatnya kondisi rumput laut menjadi rapuh dan secara perlahan akan rontok. Kondisi seperti ini sering terjadi pada waktu musim penghujan. Rendahnya salinitas perairan (kurang dari 20 ppt) juga dapat memicu terjadinya peyakit ice-ice. Sebaliknya musim panas yang berkepanjangan yang mengakibatkan suhu air laut meningkat mencapai sekitar $33^{\circ} \mathrm{C}-35^{\circ} \mathrm{C}$ yang disertai dengan kondisi arus dan 
Nally. Y.G.F. Erbabley : Identifikasi Bakteri Rumput Laut Kappaphycus alvarezii Berdasarkan Musim Tanam di Perairan Maluku Tenggara

kecerahan yang kurang mendukung dapat juga menyebabkan timbulnya penyakit iceice atau dikenal juga dengan nama white spot (Pong-Masak et al., 2009; Parenrengi et al., 2011). Menurut Santoso, dkk (2008), penyakit ice-ice pada tanaman rumput laut terjadi karena infeksi mikroba pada saat rumput laut menjadi rentan. Kondisi rentan ini disebabkan karena adanya perubahan lingkungan yang ekstrim dan tidak dapat ditolelir sehingga tanaman menjadi lemah (tidak sehat). Melemahnya rumput laut ditandai dengan cabang-cabang tanaman sedikit, keseluruhan tanaman menjadi pucat dan kaku serta permukaan thallus menjadi kasar. Pada keadaan stress rumput laut akan membebaskan substansi organik yang menyebabkan thallus berlendir dan merangsang bakteri tumbuh melimpah.

Pemantauan selama satu tahun menunjukkan bahwa pola musim tanam ini tidak sama setiap lokasi tergantung pada karakteristik iklim yang dapat mempengaruhi kondisi perairan setempat. Penerapan pola musim tanam yang baik akan menjadi bagian dari pemeliharaan lingkungan perairan, di mana pada saat musim pertumbuhan rumput laut yang tidak menguntungkan maka sebaiknya pembudidaya rumput laut berhenti untuk menanam sehingga lingkungan dapat kembali pulih seperti keadaan semula (Mudeng, 2014). Hal ini dilakukan selain dapat meminimalkan kegagalan panen karena iklim dan penyakit (Arisandi dkk, 2014), juga berfungsi untuk menjaga tingkat kesuburan perairan.

\section{Simpulan Dan Saran}

Berdasarkan hasil penelitian dapat disimpulkan bahwa : Bakteri yang ditemukan menginfeksi thallus rumput laut yang terserang penyakit ice-ice di perairan Maluku Tenggara adalah bakteri : Pseudomonas stutzeri, Aeromonas faecalis, Vibrio alginolitycus, Pseudomonas fluorescens, Actinobassilus sp dan didominasi oleh genus Pseudomonas dan Vibrio. Pada musim tanam ke III-IV periode April-Juli bakteri banyak di temukan menginfeksi rumput laut pada lokasi Sathean, sedangkan lokasi Letvuan terjadi pada musim tanam VII-VII periode OktoberDesember.

\section{Saran}

Perlu adanya penelitian lanjutan tentang tingkat serangan bakteri pada thallus rumput laut dan pengendalian penyakit ice-ice.

\section{Ucapan Terima Kasih}

Terima kasih di sampaikan kepada Bapak Dirjen Dikti, yang telah memberikan dana penelitian Hibah Bersaing dalam menunjang pelaksanaan penelitian ini. Juga kami sampaikan terima kasih kepada mitra, kepala desa dan masyarakat desa Sathean dan Letvuan yang telah memberikan kesempatan untuk melakukan penelitian selama satu tahun di wilayah petuanan.

\section{Daftar Pustaka}

Aryati. R W., Sya'rani, L., Arini E. 2007. Analisis Kesesuaian Perairan Pulau Karimunjawa dan Pulau Kemujan sebagai Lahan Budidaya Rumput Laut Menggunakan Sistem Informasi Geografis. Jurnal Pasir Laut, 3.1 :

Anggadiredja. J., T.A. Zatnika., H Purwoto dan Sri. Istini. 2011. Rumput laut (pembudidayaan, pengolahan, dan pemasaran komoditas perikanan potensial). Penebar swadaya. Jakarta.

Arisandi. A dan Akhmad. Farid, 2014. Dampak faktor ekologis terhadap sebaran penyakit ice-ice. Journal Kelautan. $7.1: 20-25$.

DKP. 2004. Profil Rumput Laut Indonesia. Jakarta-Indonesia: Direktorat Jendral Perikanan Budidaya.

Largo D.B., Fukami. K., And Nishijima. T. 1995. Occasional pathogenic bacteria promoting ice-ice diasease in the carrageenan-producing red algae Kappaphycus alvarezii and Eucheuma denticulatum

(Solieriaceae, Gigartinales, Rhodophyta). Journal of applied phyciology 7: 545 - 554.

Musa. N and L.S. Wei. 2008. Bacteria attached on cultured seaweed Gracilaria changii at Mangabang 
Telipot Terengganu Academic Journal of plant sciences 1 (1) : 01 - 04.

Mudeng. J.D., dan Ngangi. E.L.A. 2014. Pola Tanam Rumput Laut Kappaphycus alvarezii di Pulai Nain, Kabupaten Minahasa Utara. Jurnal Perikanan Universitas Sam Ratulangi. $2: 27-37$.

Neksidin. Utama., K. Pengerang dan Emiyarti. 2013. Studi kualitas air untuk budidaya rumput laut (Kappaphycus alvarezii) di perairan Teluk Kolono Kabupaten Konawe Selatan. Jurnal mina laut Indonesia. $03.12: 147-155$.

Pong-Masak P.R., dan Muh. Tjaronge. 2009. Hubungan kandungan Nitrogen dan Phosfor dalam perairan terhadap kandungannya dalam tallus rumput laut, Kappaphycus alvarezii pada lokasi berbeda di Sulawesi Selatan. Prosiding Seminar Nasional Perikanan dan Kelautan, Bidang Budidaya Perikanan. Fakultas Perikanan dan Ilmu Kelautan. Universitas Brawijaya. I. 18 - I. 25.

Parenrengi. A., Rachmansyah., dan Suryati. E. 2011. Budidaya rumput laut penghasil karaginan (Karaginofit). Balai Riset Perikanan Budidaya Air Payau, Badan Penelitian dan Pengembangan Kelautan dan Perikanan,Kementerian Kelautan dan Perikanan,

Jakarta.
Sulistijo. 2002. Penelitian Budidaya Rumput laut (Alga makro/Seaweeds) di Indonesia. Pidato Pengukuhan Ahli Peneliti Utama Bidang Akuakultur. Pusat Penelitian Oseanografi Lembaga Ilmu Pengetahuan Indonesia, Jakarta.

Santoso. L dan Yudha. Tri. Nugraha, 2008. Pengendalian penyakit ice-ice untuk meningkatkan produksi rumput laut Indonesia. Jurnal Saintek perikanan. $3.2: 37-43$.

SNI (Standart Nasional Indonesia), 2010. Produksi rumput laut kotoni (Eucheuma cottinii) - bagian 2: Metode long line. Badan standarisasi nasional. SNI : 7579.2.2010.

Supatno., Wahyu Andi Nugraha., dan Insafitri. 2010. Populasi bakteri pada rumput laut (Eucheuma cottonii) yang terserang penyakit ice-ice. Jurnal Kelautan. 3. 2.

Saraswati. S.P dan I Made Sena Darmasetiyawana. 2016. Identifikasi bakteri pada rumput laut Eucheuma spinosum yang terserang penyakit iceice di perairan pantai Kutuh. Journal of Marine and Aquatic Science 2: 11 15.

Uyenco F.R., L.S. Saniel dan G.S. Jacinto. 1981. The "ice-ice" problem in seaweed farming. 10th international seaweed symposium. Walter de gruyter, New York. pp: 625-630. 